\title{
Évolution et développement des cellules germinales / Evolution and development of germ cells
}

Centre interdisciplinaire de recherche en biologie (CIRB)

Jean-René Huynh

\section{OpenEdition}

\section{Journals}

Édition électronique

URL : https://journals.openedition.org/annuaire-cdf/16137

DOI : 10.4000/annuaire-cdf. 16137

ISBN : 978-2-7226-0572-5

ISSN : 2109-9227

\section{Éditeur}

Collège de France

\section{Édition imprimée}

Date de publication : 30 décembre 2020

Pagination : 653

ISBN : 978-2-7226-0516-9

ISSN : 0069-5580

\section{Référence électronique}

Jean-René Huynh, «Évolution et développement des cellules germinales / Evolution and development of germ cells », L'annuaire du Collège de France [En ligne], 118 | 2020, mis en ligne le 01 avril 2021, consulté le 22 août 2022. URL : http://journals.openedition.org/annuaire-cdf/16137 ; DOI : https:// doi.org/10.4000/annuaire-cdf.16137 
Latroche C., Weiss-Gayet M., Muller L., Gitiaux C., Leblanc P., Liot S., BenLarbi S., Abou-Khalil R., Verger N., Bardot P., Magnan M., Chrétien F., Mounier R., Germain S. et ChAZAud B., "Coupling between myogenesis and angiogenesis during skeletal muscle regeneration is stimulated by restorative macrophages », Stem Cell Reports, vol. 9, no 6, 2017, p. 2018-2033, DOI : 10.1016/j.stemcr.2017.10.027.

Gitiaux C., Latroche C., Weiss-Gayet M., Rodero M.P., Duffy D., Bader Meunier B., Glorion C., Nusbaum P., Bodemer C., Mouchiroud G., Chelly J., Germain S., DEsGuerre I. et ChaZAud B., «Myogenic progenitor cells exhibit IFN type I-driven proangiogenic properties and molecular signature during juvenile dermatomyositis », Arthritis \& Rheumatology, vol. 70, $\mathrm{n}^{\circ}$ 1, 2018, p. 134-145, DOI : 10.1002/art.40328.

\section{ÉVOLUTION ET DÉVELOPPEMENT DES CELLULES GERMINALES / EVOLUTION AND DEVELOPMENT OF GERM CELLS}

Responsable : Jean-René HuYNH

\section{RECHERCHE}

Pages web : https://www.college-de-france.fr/site/en-cirb/huynh.htm et http://germcells.fr.

\section{Publication}

Clémot M., Molla-Herman A., Mathieu J., Huynh J.-R. et Dostatni N., «The replicative histone chaperone CAF1 is essential for the maintenance of identity and genome integrity in adult stem cells », Development, vol. 145, n 17,2018 , DOI : 10.1242/dev.161190.

\section{MODĖLES ALÉATOIRES POUR L'INFÉRENCE DE L'ÉVOLUTION DU VIVANT / STOCHASTIC MODELS FOR THE INFERENCE OF LIFE EVOLUTION (SMILE)}

Responsable : Amaury LAMBERT

\section{RECHERCHE}

Page web : https://www.college-de-france.fr/site/en-cirb/lambert.htm.

Dirigée par Amaury Lambert (professeur à Sorbonne Université), l'équipe SMILE regroupe des mathématiciens et des biologistes de l'évolution (quatre chercheurs titulaires et huit non titulaires). 